\title{
O direito à educação no Brasil
}

CURY, Carlos Roberto Jamil. Educação e direito à educação no Brasil: um histórico pelas Constituições. Belo Horizonte: Mazza, 2014.

\author{
Marta Maria de Araújo \\ Anderson Dantas da Silva Brito \\ Israel Maria dos Santos Segundo \\ Universidade Federal do Rio Grande do Norte
}

Educação e direito à educação no Brasil: um histórico pelas Constituições, é mais uma produção acadêmica do professor e pesquisador Carlos Roberto Jamil Cury, estudioso da educação escolar em suas intersecções com a cidadania, direitos civis, deveres, laicidade, federalismo, democracia e financiamento público, principalmente nas Constituições Nacionais Brasileiras. A sua definição de Constituição Nacional já revela o quão é profundo estudioso. Uma Constituição Nacional - define Cury (2014, p. 8) - é a expressão de um pacto pela existência social, "[...] assinala o conjunto mais elevado de princípios, prescrições e dispositivos para a autonomia e soberania de uma nação". Logo, a resenha justifica-se pela relevância para a história da educação e a história do direito à educação primária para todos, principalmente.

No capítulo "Educação e Constituições nacionais" Cury analisa o processo de positivação do direito à educação escolar nas Constituições Nacionais. Na Constituição Política do Império do Brasil de 1824, conforme Cury (p. 25), a educação especialmente a educação primária "[...] foi considerada um direito civil e político da nova nação". Entretanto, o direito à educação era para aqueles nascidos livres, naturalizados e libertos. Nas Constituições da República dos Estados Unidos do Brasil de 1934 e 1946, a educação escolar primária gratuita e obrigatória como direito competia a sua efetivação aos Estados federados e aos municípios. Essas proposições se apoiam - segundo Cury (p. 30) - " [...] em um federalismo educacional, no qual as diretrizes e bases da educação são da alçada da União". 
Na Constituição (ortogada) da República dos Estados Unidos do Brasil de 1937, a educação escolar primária (embora gratuita e obrigatória), como direito, era dever proeminente da familia e dever subsidiário dos Estados federados e muncipios. Na Constituição da República Federativa do Brasil de 1967, a educação escolar primária gratuita e obrigatória lampliada para oito anos) era um direito e o dever de ministrá-la pela familia e pelos poderes públicos.

Na Constituição da República Federativa do Brasil de 1988, a educação primária gratuita obrigatória era direito de todos e dever dos poderes públicos de promover. Pelas explicações de Cury (p. 43), a Constituição Republicana de 1988 reconheceu a educação como o primeiro dos direitos sociais do cidadão e dever do Estado. "E, por essa razão, estabeleceu princípios, diretrizes, regras, recursos vinculados e planos, de modo a dar substância a esse direito." A educação, como direito de todos, foi traduzida pelo conceito de educação básica - segundo Cury (p. 49) - conceito expresso numa "[...] declaração de direito de todos a ser realizada em uma educação escolar que contivesse elementos comuns".

No capítulo "Do Direito à Educação e Federalismo" discute-se o direito 296 à educação com base em conceitos fundamentais como o conceito de federação. A federação - conceitua Cury (p. 56) - "[...] é a união de membros federados que formam uma só entidade soberana: o Estado Nacional". No regime federativo, portanto, os poderes de governo são distribuídos pelas instâncias governamentais mediante competências legalmente definidas.

A nação brasileira que tem como forma de governo a República Federativa (Decreto $n^{\circ} 1$, de 15 de novembro de 1889) e outras nações, tais como Alemanha, Argentina, Bélgica, Estados Unidos, Rússia e Venezuela, sobressaem como exemplos formalizados de federalismo político, embora como esclarece Cury, diferenciadas nas suas especificidades e efetivação.

$\bigcirc$ princípio do direito à educação, instituído na Constituição da República Federativa do Brasil de 1988, as diretrizes constantes na Lei de Diretrizes e Bases da Educação Nacional (Lei n 9.394, de 20 de dezembro de 1996), bem como o caráter federativo da nação brasileira, por conseguinte, para efetivação do direito à educação para todos observou Cury lp. 61): constata-se "[...] um sistema de reparticação de competências e atribuições legislativas entre integrantes do sistema federativo dentro de limites 
expressos, reconhecendo a dignidade e a autonomia próprias deles". Portanto, o princípio do direito à educação efetiva-se em regime de colaboração entre a União, Estados e Municípios no exercicio de um Estado Democrático de Direito.

No item da "Conclusão", Cury (p. 65) chama atenção à efetivação do direito à educação escolar para todos em países como o Brasil, aberto sob condições, à iniciativa privada, "[...] é, no âmbito público, cercado de proteção, como exemplo, a Constituição, a Lei de Diretrizes e Bases da Educação Nacional, o Plano Nacional de Educação e os pareceres e resoluções dos Conselhos de Educação".

Enfim, a educação escolar (infantil, básica e universitária) como um direito social e um direito de cidadania dos brasileiros presume-se que todos os indivíduos são sujeitos desse direito fundamental. A efetivação da educação escolar, como um dos direitos fundamentais de cada criança, do jovem e do adulto, é, exatamente, o que qualifica o Estado Democrático de Direito.

Profa. Dra. Marta Maria de Araújo Universidade Federal do Rio Grande do Norte Departamento de Fundamentos e Políticas da Educação Programa de Pós-Graduação em Educação Grupo de Pesquisa Estudos Históricos Educacionais (UFRN-CNPq) E-mail |martaujo@uol.com.br

Anderson Dantas da Silva Brito Doutorando do Programa de Pós-Graduação em Educação Universidade Federal do Rio Grande do Norte Grupo de Pesquisa Estudos Históricos Educacionais (UFRN-CNPq) E-mail | andersondsb 16@yahoo.com.br

Israel Maria dos Santos Segundo Mestrando do Programa de Pós-Graduação em Educação Universidade Federal do Rio Grande do Norte 
Resenha

direito à educação no Brasil

Grupo de Pesquisa Estudos Históricos Educacionais (UFRN-CNPq) E-mail | leao.israel10@hotmail.comr

Recebido ${ }^{\circ}$ out. 2016

Aceito 6 nov. 2016 